\title{
Flower Behavior of Different Avocado Varieties Grown in Puerto Rico
}

\section{R. Abrams, W. Pennock, G. C. Jackson, and A. Pérez López ${ }^{1}$ \\ INTRODUCTION}

The avocado variety collection grown at the Isabela Experiment Substation is the largest on the Island. It was first established in May 1945, and today this collection comprises 484 trees representing 117 varieties of the West Indian, Guatemalan, and Mexican races. Over 80 of these varieties are fairly recent local selections which have not yet been described. This study was conducted in order to classify the avocado varieties grown at the Isabela Experiment Substation according to flower behavior.

\section{REVIEW OF THE LITERATURE}

As first shown by Nirody $(1)^{2}$ such flower behavior falls into two distinct patterns in avocados, which may differ for different varieties, but remain constant for all individuals of the same variety. Knowledge of the flower behavior of avocado varieties is of considerable importance, both for commercial as well as botanical reasons. Flower class in avocados is an unequivocal characteristic which, on occasion, can be most helpful in distinguishing between similar varieties. It should, therefore, be included when possible in the description of a new variety. Commercially, knowledge of flower class can be of considerable importance in obtaining better fruit set or yield in the orchards since any planting should consist of a combination of several varieties calculated to facilitate frequent cross-pollination.

The flowers of avocados are perfect flowers produced in large numbers during a blooming period of several weeks. Each flower has one pistil and 12 stamens in four series or whorls. Nine of these stamens are functional and the three innermost, located opposite the inner perianth segments, have the stamens reduced to staminodia (s).

\section{FLOWER CYCLE}

All avocado flowers are subject to dianthesis and dichogamy. In other words, each flower has two separate, distinct periods of opening, and the male and female elements become functional at different times. According to Stout (2), avocado varieties fall into two general classifications which

1 Research Assistant in Agronomy, Horticulturist, Research Assistant in Horticulture, and Research Assistant in Agronomy, respectively, Agricultural Experiment Station, University of Puerto Rico, Río Piedras, P. R.

Italic numbers in parentheses refer to Literature Cited, p. 241. 
he has designated as A and B types. In both types the flowers first mature as females, close for a fixed period, and later reopen as mature males. In the A type, however, the first or female opening occurs in the morning whereas with the B type the first or female opening occurs in the aftemoon.

For any individual A flower the cycle of dianthesis consists of opening in the morning as female, closing around midday and remaining closed for approximately 24 hours, and opening the next day as a male in the afternoon. In the A-type tree all the flowers that first open on the same day will follow this cycle synchronously, but on each successive day a new set of flowers will initiate the cycle, thus providing a succession of female functional flowers every morning, and a succession of male functional flowers every afternoon during the blooming period.

For any individual B flower the cycle consists of first opening as a female in the afternoon, closing for a period, depending on variety, of either 12 or 36 hours, approximately, and opening for the second time as a male functional flower in the morning of the following day or of the second day. In the B-type tree a successive set of flowers will first open as females in

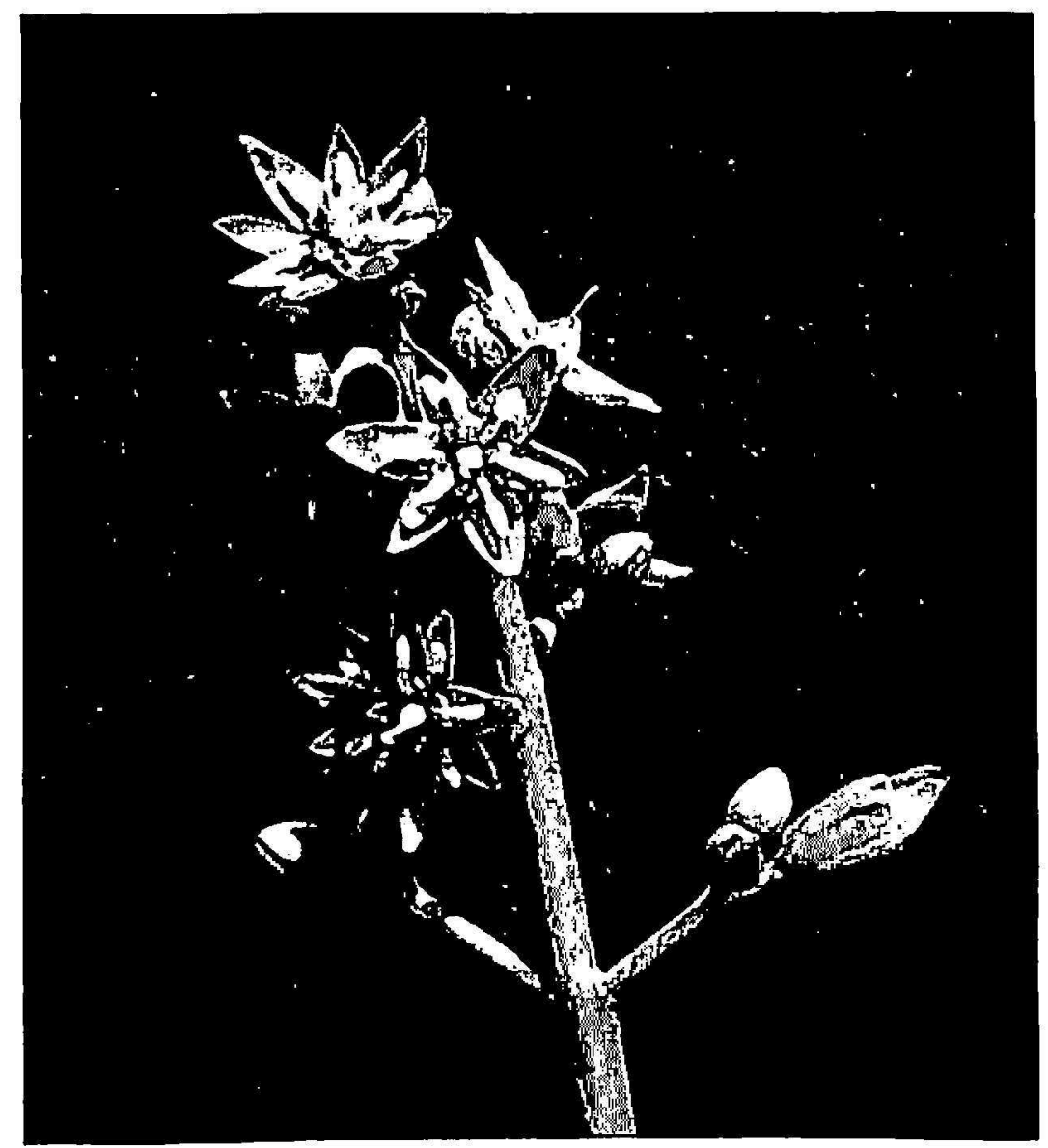

Fici. 1.-Avocado flowers during the first or female opening. The stamens lie flat against the petals and the cent ral pistil stands erect with the stigma ready to receive pollen. 
the afternoon of each succeeding day, thus also establishing a succession of flowers which will open as males every morning during the blooming period.

The essential elements of avocado flower behavior can, therefore, be summarized briefly as follows:

1. A-type trees behave as females in the morning and as males in the afternoon.

2. B-type trees behave as females in the afternoon and as males in the morning.

3. The two types complement each other, making cross-pollination between them almost a certainty and self-pollination highly improbable.

\section{CLASSIFICATION AS TO FLOWER BEHAVIOR}

A- and B-type flowers are identical structurally. It is very easy, however, to distinguish between female functional flowers at a glance. It is therefore a simple matter to classify varieties as to flower-behavior type. In the first or female opening of any flower the stamens lie flat against the petals and the central pistil stands erect alone and conspicuous with its stigma

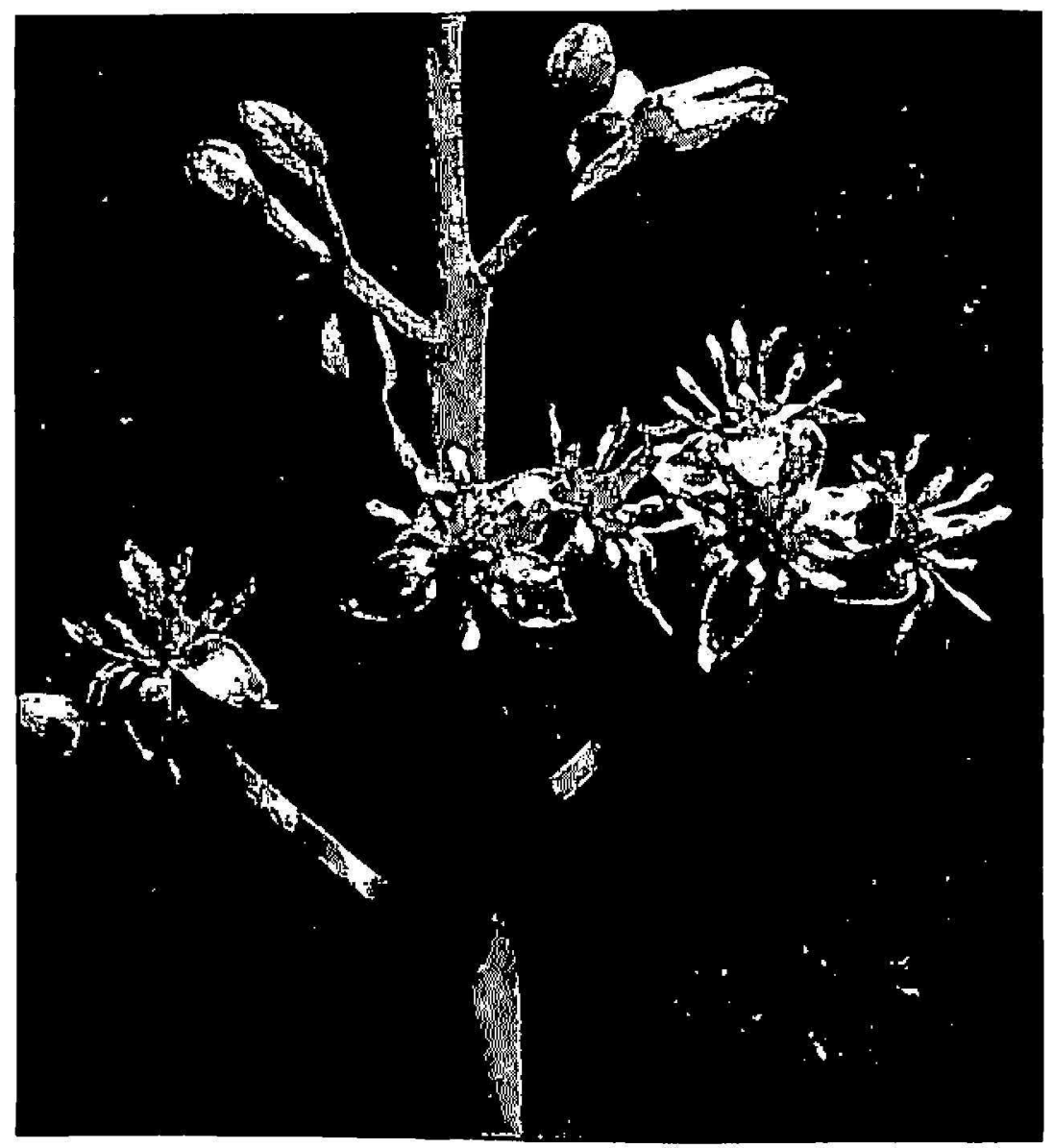

Fici. 2.-Avorado flowers during the second or male opening. The stamens are upright and prominent. The inner 3 stand erect around and overtopping the pisti]; the outer 6 siland all an angle of 45 degrees. 
white and fresh, ready to receive pollen (fig. 1). In the second or male opening the numerous stamens are upright and prominent. The inner three stand erect in the middle of the flower around and overtopping the pistil; the outer six stamens stand at an angle of about 45 degrees (fig. 2).

All of the varieties observed in flower at the Isabela Substation collection are listed below in accordance with flower-behavior class. The list includes some well-known Florida and California varieties and also many local selections which have not yet been described. A manuscript describing these varieties is now being prepared and will doubtless soon appear in print.

Class $A$ Varieties

Adjuntas Guatemala

Adjuntas seedling

Avila

Butler

Castañer

Choquette

Collinson

Dickinson

Dulce

Frank

Fuschia

Gripiña 1

Gripiña 9

Gripiña 10

Gripiña 20

Hernández

Guatemala

Isabela 2

Isabela 28

Isabela 38

Isabela 41

Isabela 68

Isabela 86

Isabela 109

Isabela 111

Isabela 116

Isabela 138

Isabela 147

Isabela 155

Isabela 178
Class B Varieties

Booth 7

Booth 8

Donalson

Fuerte

Fuerte sdg. No. 6

Galo

Gripiña 2

Gripiña 3

Gripiña 4

Gripiña 5

Gripiña 6

Gripiña 7

Gripiña 8

Gripiña 11

Gripiña 12

Gripiña 13

Gripiña 14

Gripiña 15

Gripiña 16

Gripiña 18

Gripiña 19

Hall

Hickson

Isabela 1

Isabela 14

Isabela 21

Isabela 126

Isabela 152

Isabela 167

Isabela 179 


$\quad$ Class A Varieties
Isabela 186
Isabela 188
Isabela 221
Isabela 227
Isabela 236
Isabela 330
Isabela 354
Kanan
Kanan sdg. No. 1
Kanan sdg. No. 2
Las Mesas 221
Lula
Perfecto
P.R.R.A. 1
Quebradillas sdg. No. 6
Semil 23
Semil 25
Semil 31
Semil 34
Semil 35
Semil 39
Semil 41
Semil 44
Semil 45
Wilson Popenoe
77011

Class $B$ Varieties

Isabela 182

Isabela 204

Isabela 219

Isabela 233

Isabela 360

Itzamna

Johnston

K-7 No. 2

Knight

Las Mesas 222

Meléndez 2

Méjico Negro

Monge

Nabal

Panchoy

P.R.R.A. 18

Schediana 154

Semil 11

Semil 26

Semil 30

Semil 37

Semil 38

Semil 40

Semil 43

Semil 46

Semil 47

Tertoh

Trapp sdg. No. 4

Utuado 1

Yon

Vannel Late

Winslowson

\section{SUMMARY}

This paper presents the flower behavior of 118 varieties of avocados grown at the Isabela Experiment Substation. Knowledge of the two distinct patterns of flower behavior in avocados can be of great importance in obtaining better fruit set in the orchards since any planting should consist of a combination of several varieties to facilitate frequent crosspollination.

Flowers of avocado varieties mentioned in this study were classified as 
A and B types. Those in type A open in the morning as females, close at noon, stay closed for 24 hours, more or less, and open next day as males. Type-B flowers open as females in the afternoon, stay closed for 12 to 36 hours, approximately, according to variety, and then open on the subsequent morning as males. The two types complement each other, thus insuring cross pollination and making self-pollination highly improbable.

The list presented of avocado varieties studied and classified as to flower behavior includes some well-known Florida and California varieties and also many local varieties which have not yet been described.

\section{RESUMEN}

Este estudio presenta el comportamiento en cuanto a la inflorescencia de 118 variedades de aguacates actualmente bajo cultivo en la Subestación Experimental Agrícola en Isabela. Es de gran importancia conocer las dos distintas normas de inflorescencia de los árboles de aguacate, ya que los plantíos de esta fruta deben tener una combinación de varias variedades para así facilitar una constante polinización cruzada.

Las flores de las variedades incluídas en este estudio fueron clasificadas en dos tipos: A y B. Las flores del tipo A abren en la mañana como hembras, se cierran al mediodía y así permanecen, más o menos por 24 horas, hasta que abren de nuevo en la tarde como machos. Las del tipo $B$ abren como hembras durante las horas de la tarde, se cierran por 12636 horas, según la variedad, y abren en la mañana subsiguiente como machos. Ambos tipos se complementan entre sí, asegurando la polinización cruzada y casi eliminando la auto-fertilización.

\section{LITERATURE CITED}

1. Nirody, B. S., Investigations in Avocado Breeding, Annual Report, Calif. Avocado Assn., 1921-22.

2. Stout, A. B., The Pollination of Avocados, Fla. Agr. Exp. Sta. Bul. 257, 6-10, 1933.

3. Wolfe, H. S., Toy, L. R., and Stahl, A. L., Avocado Production in Florida, Fla. Agr. Ext. Serv. Bul. 129, 14-15, 1946. 